\title{
Publicly Committed to the Good: The State of Nature and the Civil Condition IN Right AND IN ETHICS
}

\author{
- Stefano Lo Re -
}

\begin{abstract}
In Religion within the Bounds of Bare Reason Kant speaks of an ethical state of nature and of an ethico-civil condition, with explicit reference to the juridical state of nature and the juridico-civil condition he discusses at length in his legal-political writings. Given that the Religion is the only work where Kant introduces a parallel between these concepts, one might think that this is only a loose analogy, serving a merely illustrative function. The paper provides a first outline of the similarities and the differences between the state of nature and the civil condition in Right and in ethics. The comparison points to a deeper, structural relation between the two pairs of concepts. By doing so, it makes room for developing a unitary conception of the state of nature and of the civil condition, which would underlie both the ethical and the juridical version.
\end{abstract}

Keywords: Kant, Right, religion, state of nature, civil condition, ethical community, publicity.

Published online: 20 August 2020

\section{Introduction}

In Religion within the Bounds of Bare Reason (1793), Kant speaks of an "ethical state of nature [der ethische Naturzustand]" and of an "ethically civil condition [ein ethisch-bürgerlicher Zustand]," with explicit reference to the "juridical state of nature [der juridische Naturzustand]" and the "juridically civil (political) condition [ein rechtlich-bürgerlicher (politischer) Zustand]"1 he discusses at length in his writings on legal-political philosophy - most notably, his 1797 Doctrine of Right. Given that the Religion is the only work where Kant develops this parallel, one might be inclined to think that this is simply a loose analogy, which he introduces merely for illustrative purposes. According to this line of thought, it would be mainly for reasons of convenience that Kant employs that legal-political terminology in the ethical-religious sphere, but the relation between the two families of concepts

\footnotetext{
Stefano Lo Re

Centre for Ethics, Philosophy and Public Affairs

University of St Andrews

St Andrews

KY16 9AL

Scotland

email: stelore87@gmail.com

${ }^{1}$ RGV 6:95, trans. altered. With the exception of the first Critique, for which I employ the customary A/B system, when citing Kant I refer to volume and page in the Akademie-Ausgabe (Kant (1900-)), from which I also take the quotes in German.
} 
remains superficial. In this paper, I offer a first outline of the similarities and differences between the natural and the civil condition in Right and in ethics. ${ }^{2}$ The comparison points to a deeper, structural relation between the two pairs of concepts. By doing so, it makes room for developing a unitary conception of the state of nature and of the civil condition, which would underlie both the ethical and the juridical version.

In the first section, I provide context by outlining Kant's juridical state of nature (§1.1) and his doctrine of radical evil (\$1.2). Then, I discuss four points of comparison between juridical and ethical conditions, concerning coercion (\$2.1); their scope (\$2.2); the necessity of representation (\$2.3); and the notions of legitimacy and justice (\$2.4). In the third section, I introduce two features of Kant's conception of the duty to exit the ethical state of nature, regarding assurance (\$3.1) and publicity (\$3.2-3). Finally, I articulate the function of the ethico-civil condition into three dimensions: political (\$4.1), moral-organisational (§4.2), and moral proper (§§4.3-4).

\section{Preliminaries}

This section provides context to the subsequent discussion by outlining Kant's juridical state of nature (\$1.1) and his doctrine of radical evil (\$1.2). I will only give a rough sketch for present purposes, with no aim to settle the complex details of these hotly debated elements of his theory. ${ }^{3}$

\subsection{The Juridical State of Nature}

Kant's state of nature is better known in its juridical-political version. The juridical state of nature and its opposite, the juridically civil condition, appear in all of his main writings on legal and political philosophy. ${ }^{4}$ Arguably, the most extensive treatment of this notion is contained in the Doctrine of Right, the first part of Kant's Metaphysics of Morals (1797). There, the state of nature is described as a "condition [Zustand] of externally lawless freedom." ${ }^{5}$ In this condition, individuals only have 'provisional' rights, which are precarious because each one is entitled to enforce one's own judgments about rights: individuals "can never be secure against violence from one another, since each has its

\footnotetext{
${ }^{2}$ The English translation ('state of nature', 'civil condition') obfuscates the parallel between the conditions (or states, situations - statūs in Latin, Zustände in German). Strictly speaking, one could replace 'state of nature' with 'natural condition' (Kant himself speaks of "status naturalis" in contrast with "status civilis"; RL 6:306). I will mainly use the well-established English terms, but I will sometimes speak of 'conditions' to refer collectively to the states of nature (ethical and juridical), the civil conditions (ethical and juridical), or both.

${ }^{3}$ On Kant's juridical state of nature see, for example, Byrd, Hruschka (2008); Ebels-Duggan (2012); Ripstein (2009); Varden (2010); on his doctrine of radical evil, see Formosa (2007); Morgan (2005); Muchnik (2009); Papish (2018). Michalson (2014) contains an invaluable selection of contributions on Kant's Religion.

${ }^{4}$ In addition to the Doctrine of Right, see Theory and Practice (e.g. TP 8:289), and Perpetual Peace (e.g. ZeF 8:346; 8:349 n.; 8:375). Students' lecture notes such as Feyerabend and Vigilantius also discuss these notions at various points (e.g. V-NR/Feyerabend 27:1338; V-MS/Vigil 27:515); see also Kant's review of Hufeland's "Essay on the Principle of Natural Right" (RezHufeland 8:128).

${ }^{5}$ RL 6:307, trans. altered.
} 
own right to do what seems right and good to it and not to be dependent upon another's opinion about this." ${ }^{1}$ Although individuals do not wrong each other in this condition, "they do wrong in the highest degree" 7 by remaining in it. Accordingly, they all have a right and a duty to enter a (juridically) civil condition, i.e. to be subject to "a public lawful external coercion" ${ }^{8}$ : in this condition, the rights of each are determined by law and secured against other individuals by adequate coercive power.

For the sake of my subsequent discussion, I should introduce the following points, more by way of an assumption than of an articulate defence. Firstly, when we talk about the juridical state of nature and the necessity to exit it, we are in the territory of what one may permissibly be forced to do. ${ }^{9}$ The focus is on individuals' external freedom: unlike ethics, Right (Kant's legal-political philosophy) is not concerned with whether individuals comply with laws from duty, and rather admits externally coercive incentives. ${ }^{10}$ Within this framework, coercion against unlawful actions is a "hindering of a hindrance to freedom."11

Secondly, a condition of lawless freedom is, according to Kant, a contradiction in terms, as freedom - both the external freedom of Right and the inner freedom of ethics - consists essentially in lawgovernedness. ${ }^{12}$ This goes some way to explain Kant's idea that individuals do 'wrong in the highest degree' by remaining in the state of nature even if, within it, it is impossible for them to wrong each other.

Thirdly, and relatedly, the problem in the state of nature is that interaction among individuals is "morally incoherent," 13 since "nobody is under any obligation to defer to the deeds, claims, or judgments of others." ${ }^{14}$ Kant is concerned neither with how individuals can guarantee their own best prudential interest, nor with the possibility that some may impose their conception of the good on others, nor with distributive justice in the contemporary sense. The main question of his legal-political philosophy is how individuals can act (externally) freely. The answer lies in the articulation of "the conditions under which the choice of one can be united with the choice of another in accordance with a universal law of freedom,"15 Kant's very definition of Right.

Finally, the necessity of exiting the state of nature does not stem from individuals' moral imperfection. In the Doctrine of Right, Kant famously remarks that individuals must seek a civil condition "however well disposed and law-abiding"16 they might be. Individuals' moral dispositions play no role in Kant's argument for the duty to exit the state of nature. ${ }^{17}$

\footnotetext{
${ }^{6}$ RL 6:312. For a recent discussion of the provisional nature of rights in the state of nature, see Hasan (2018).

7 RL 6:307.

8 RL 6:312.

${ }^{9}$ Ripstein (2009): 14.

${ }^{10}$ RL 6:218-219.

${ }^{11}$ RL 6:231, emphasis removed. For a careful elaboration of this idea, see Ripstein (2004).

${ }^{12}$ Flikschuh (2017): 75.

${ }^{13}$ Ripstein (2009): 183.

${ }^{14}$ Ripstein (2009): 147.

${ }^{15}$ RL 6:230.

16 RL 6:312.

${ }^{17}$ This is particularly controversial. In the Feyerabend lecture notes Kant reportedly argues that if human beings were well-disposed, exit from the juridical state of nature would be unnecessary
} 


\subsection{Radical Evil}

According to Kant, human nature is characterised in its very idea by a composite predisposition (Anlage) to the good. ${ }^{18}$ The multiple predispositions falling under it are predispositions to the "animality," the "humanity," and the "personality" of the human being as, respectively, a living being, a living and rational being, and a rational being "capable of imputation [of actions to him - WP]." ${ }^{19}$ Such predispositions are "original," Kant explains, "because they belong to the possibility of human nature" and do so "necessarily." 20

At the same time, human nature is also characterised by a "propensity [Hang] to evil." ${ }^{21}$ Propensities in general are distinguished from predispositions in that the former do not have to be original: in particular, the propensity at issue here is evil because it is "brought upon the human being by himself." 22 This evil consists in the possibility that human beings deviate from the moral law. Although Kant distinguishes three levels of the propensity to evil, the main one is that whereby the human being subverts the correct order of priority between the incentive of duty and that of inclinations. ${ }^{23}$ According to Kant, the "radical, innate evil in human nature" consists in the fact that the human being "is conscious of the moral law and yet has admitted the (occasional) deviation from it into his maxim." 24 The duty incumbent on each human being is to restore the supremacy of the moral law as the incentive of all maxims. ${ }^{25}$ This involves a deep inner reorientation, a "change of heart" that can only occur by means of a "revolution," and not by "gradual reform." 26

Until the third piece of the Religion, one is led to think that each individual is equipped to seek such change of heart by oneself, in a way that is self-sufficient - with the possible exception of God's mysterious assistance, i.e. grace. ${ }^{27}$ However, the third piece opens with the disheartening remark that although the single human being may attain "liberation from the dominion of the evil principle ... [he] nonetheless continues to remain exposed to [its attacks, and therefore must] always remain armed for struggle." 28 The main reason why the individual's change of heart is insufficient, Kant argues, is

(V-NR/Feyerabend 27:1381). Ripstein, who champions the view summarised in the main text, sees this as an earlier view which Kant eventually abandoned (Ripstein (2009): 163 n. 24). Byrd and Hruschka, instead, use Kant's doctrine of radical evil as key to the duty to exit the juridical state of nature (Byrd, Hruschka (2008)). Here I am more on Ripstein's side concerning the interpretation of this duty. However, Byrd's and Hruschka's treatment of Kant's employment of 'presumptions' (the presumptions of goodness and innocence as juridical propositions, and the ethical presumption of badness as grounding the duty to exit the juridical state of nature) would deserve further discussion in the project of relating the ethical and the juridical conditions (for example, see my reference to assurance in the context of the ethical state of nature in \$3.1). I cannot undertake that discussion here.

${ }_{18}$ RGV 6:26.

${ }^{19}$ Ibidem.

${ }^{20}$ RGV 6:28.

${ }^{21}$ Ibidem.

${ }^{22}$ RGV 6:29.

${ }^{23}$ RGV 6:29-30.

${ }^{24}$ RGV 6:32, emphases removed.

${ }^{25}$ RGV 6:46.

${ }^{26}$ RGV 6:47, emphases removed.

${ }^{27}$ RGV 6:53; 6:118.

${ }^{28}$ RGV 6:93. 
the mere presence of other individuals (§3.1). It is at this point in the argument that he introduces the notion of ethical community, as well as the opposite notions of ethical state of nature and ethically civil condition, the ethical counterparts to the juridical state of nature and the juridically civil condition.

\section{Ethical and Juridical Conditions: Differences and Similarities}

In this section I run a comparison between the ethical and the juridical conditions (natural and civil). The idea behind the comparison is that if the results appeared contrived, that would speak against considering Kant's recourse to the terminology of Right as serving anything more than an illustrative function. If, instead, the connections looked convincing, then we would have reason to explore the relation between the conditions in further detail. Note that such connections need not consist only of similarities: differences can be admitted insofar as they can be traced to systematic features of Kant's thought, particularly regarding the distinction between ethics and Right.

\subsection{Coercion}

The first point of comparison concerns external coercion. As mentioned earlier (\$1.1), Right is the sphere of Kant's practical philosophy concerned with what individuals may legitimately be coerced to do by others. For example, one has a coercive right that others do not steal from one, and the state can legitimately impose threats of punishment and execute them in order to protect this right. Ethics, instead, is beyond the reach of this coercion, and only has to do with what one imposes on oneself:

When, instead of coercion from without, inner freedom comes into play, the capacity for self-coercion [des Selbstzwanges] not by means of other inclinations but by pure practical reason ... the concept of duty is extended beyond outer freedom, which is limited only by the formal provision of its compatibility with the freedom of all. ${ }^{29}$

The focus of ethics is on the exercise of rational guidance over inclinations by means of a correct ordering of incentives (\$1.2) and on the adoption of certain obligatory ends (one's own perfection and the happiness of others), neither of which can be forced on one. ${ }^{30}$ For example, one should refrain from stealing because it is a duty, independently of sanctions; and, one should adopt a maxim of beneficence. This general difference between Right and ethics is reflected in the distinction between ethical and juridical conditions. Not only do the ethical conditions not have to do with coercible actions, but exit from the ethical state of nature cannot be coerced - an impossibility which, according to Kant, is both conceptual and normative: the ethical community "in its very concept ... carries with it freedom from coercion," and individuals are "entitled ... to remain in [the ethical state of nature]." ${ }^{31}$

${ }^{29}$ TL 6:396, trans. altered.

${ }^{30}$ RL 6:219-220; TL 6:382-388; 6:392-394.

${ }^{31}$ RGV 6:95. It is plausible that the ethical community is, in the terminology of the first Critique, a "dynamic community": it is not "communio," a mere co-existence in the sharing of certain features, but 


\subsection{Scope}

One might see a difference in scope between the juridically and the ethically civil condition: whereas the former is instantiated in a specific territory, the thought would go, the latter is meant to encompass the entire Earth. After all, Kant says that "the concept of an ethical community is always referred to the ideal of the whole of all human beings," which "distinguishes it from the concept of a political community." ${ }^{22}$ On further reflection, however, the difference does not hold up.

Firstly, when considering the juridical conditions, one must take into account all the levels of Right. These include not only private right and the right of a state (roughly, the level of interaction between individuals in isolation from the state; and that of their interaction under a state, which includes the state's prerogatives); but also "the right of states in relation to one another," ${ }^{33}$ with its goal of international institutional arrangements guaranteeing peace; and "cosmopolitan right," 34 which, among other things, safeguards the possibility of interaction (commercial, but not only) between individuals, states, and peoples. ${ }^{35}$ The relation between all these levels is a complicated matter, which I must set aside. However, the last two levels clearly attest to the global commitments of Kant's juridical-political theory: the individual states are at best intermediate entities in the architectonic of Right.

Secondly, in the Religion Kant writes that "a multitude of human beings" united under ethical commitments is not "the ethical community itself," but rather "a particular society that strives toward agreement with all human beings." ${ }^{36}$ Moreover, he explicitly likens such particular societies, in their relation with each other so far as they are separate, to "different political states that are not connected by a public law of nations." ${ }^{37}$

Thirdly, and relatedly, Kant seems to conceive of the all-encompassing version of both the juridical-political community and the ethical community as a regulative ideal and as an unattainable goal..$^{38}$ The distinction between particular ethical societies and the ethical community itself seems to be orthogonal to that between what he calls invisible and visible church. The former church is "a bare idea of the union of all righteous people under the divine direct but moral government of the world," whereas the latter church is "the actual union of human beings to form a whole that harmonises with that ideal." 39 My point here is that the visible church does not refer to particular ethical societies (in this sense, it might be infelicitous to speak of visible churches, in the plural), but rather to their unity - which, however distant in the future, would still constitute an (imperfect) empirical instantiation of the invisible church.

rather "commercium," characterised by "reciprocal influence" (KrV A213/B 260). After all, membership to the ethical community has a morally beneficial impact on individuals, an active and reciprocal influence (or so I shall argue; §4). See also n. 86.

${ }^{32}$ RGV 6:96.

${ }^{33}$ RL 6:343, emphasis removed.

${ }^{34}$ RL 6:352.

${ }^{35}$ On cosmopolitan right, see Niesen (2007).

${ }^{36}$ RGV 6:96.

37 Ibidem.

${ }^{38}$ RL 6:350; ZeF 8:386; RGV 6:100.

${ }^{39}$ RGV 6:101. 
On the basis of these remarks, we can cautiously conclude that the juridical and the ethical conditions do not differ in their scope: although with intermediate levels, they ultimately encompass the entire Earth. ${ }^{40}$

\subsection{Representation}

According to Kant, a people, as an entity belonging to the sphere of Right, does not pre-exist institutional and political representation. As put by Katrin Flikschuh: "no people without the idea of a general united will, and no general united will without a government to represent it." ${ }^{41}$ Assuming this is correct, the corresponding claim in ethics would be, I believe, that the multitude of individuals composing particular - 'local', so to speak - ethical societies do not pre-exist, as a people, representation into a church.

When Kant speaks of the concept of an ethical community as "the concept of a people of God under ethical laws, ${ }^{42}$ he refers to the invisible church. ${ }^{43}$ Whereas in the case of a juridically civil condition it is the people that must be capable of being thought of as the legislator, ${ }^{44}$ within the ethical community it is God who is thought of as "supreme legislator" ${ }^{\prime \prime}$ : not so much in the sense of being author of ethical laws (which, as such, can have no author), but rather as author of the obligation connected to them. ${ }^{46} \mathrm{Now}$, if the idea of God acts as a unifying principle of the ethical community, then it is plausible to think of ethical societies as replicating this structure-as imitating the archetype, as it were: just as in the juridical case, while the idea of the community has its validity independently of its instantiation, ${ }^{47}$ the concrete societies do not pre-exist their representation under a unifying principle.

This is the case even despite the absence of an analogue for the general united will in the ethical realm, which is not to deny that each ethical society will have to make decisions on a variety of issues. In fact, later in the Religion, Kant returns to the analogy between people and God, speaking of the latter as the "originator of the constitution" of the visible church, whereas its members are in charge of its "organisation." 48

\footnotetext{
${ }^{40}$ There is, however, a difficulty. While it is rather intuitive to conceive of the ethical community as including all rational finite beings (besides, of course, God as its head; RGV 6:98-100), and although principles of Right in their most abstract form might be said to apply to all rational finite beings, the Doctrine of Right does seem to have a specific focus on human beings (think also about the key role of the Earth's limited surface for Kant's arguments there; RL 6:262; 6:352; see Flikschuh (2000)).

${ }^{41}$ Flikschuh (2008): 143. For a general discussion of juridical-political representation in Kant, see Pinzani (2008). The claim in the main text sets aside the thorny issue of the status of non-state peoples in Kant's philosophy of Right. See Flikschuh (2017): 37-68; Niesen (2007).

${ }^{42}$ RGV 6:98.

${ }^{43}$ Kant writes that an ethical community "regarded as a church [is] a mere representative of a state [ruled by] God" (RGV 6:102, emphasis removed), but in the context of denying that it is characterised by anything like a political constitution.

${ }^{44}$ RL 6:313-314; TP 8:304-305.

${ }^{45}$ RGV 6:99. He is also conceived of as "moral ruler," with reference to the idea of apportioning happiness in proportion to virtue (RGV 6:99). See \$3.2.

${ }^{46}$ RL 6:227. For a discussion of this doctrine, see Kain (2004); Timmermann (2018).

${ }^{47}$ An idea is "a necessary concept of reason for which no congruent object can be given in the senses" (KrV A 327/B 383).

${ }^{48}$ RGV 6:152. Demiray's consent-based reading of the authority of what I call ethical societies implicitly attributes something akin to a general united will to them (Demiray (2017): 40). In so doing, Demiray also extends a political conception of legitimacy to ethical societies (on which see the next subsection).
} 


\subsection{Legitimacy and Justice}

The secondary literature on Kant's juridical-political philosophy distinguishes a state's legitimacy from its justice. ${ }^{49}$ According to Kant, the exercise of power must meet certain basic conditions in order to count as legitimate: without this, individuals are left in a situation where might makes right, which effectively amounts to a state of nature. Only once the institutional and political arrangements satisfy such basic conditions does the application of criteria of justice first become possible. Typically, the duty captured by Kant's postulate of public right is considered the criterion for legitimacy: "when you cannot avoid living side by side with all others, you ought to leave the state of nature and proceed with them into a rightful condition," ${ }^{50}$ namely a condition of distributive justice (in Kant's technical sense: one where "what belongs to each can be secured to him against everyone else" $\mathrm{e}^{51}$ ). The idea of original contract, the "idea of the agreement of all who are subject to the law," 52 is "the internal criterion" of the justice of the state, that is "for assessing and, where appropriate, improving an existing rightful condition." 53 The question now arises: are there possible ethical counterparts for legitimacy and justice as juridico-political notions?

According to Kant, the visible church is inevitably deficient relative to the ideal it represents. There is a parallel, here, with his idea that no state is ever fully just - no real state can ever instantiate perfectly the ideal state. ${ }^{54}$ This parallel speaks in favour of trying to locate an ethical counterpart at least for justice. In the Religion Kant lists a series of "requirements" for the "true (visible) church": "numerical unity"; "purity" - being a "union under no incentives other than the moral ones," namely devoid of "superstition" and "fanaticism" - "freedom" of its members in relation to one another, as well as of the church in relation to political power, and "unchangeability according to its constitution." 55 A visible church which presented these marks would, presumably, be the "true (visible) church." ${ }^{56}$ As a speculation, we might conceive of these as applying to the multitude of ethical societies, as criteria for the analogue of justice in the ethical-religious sphere.

As to legitimacy, in the fourth piece of the Religion Kant introduces a difference regarding whether the officials of churches (actual churches, ethical societies) adopt the goal of approximating "pure rational faith" 57 and of gradually dispensing with the historical element of faith. Church officials who do so provide

\footnotetext{
49 Byrd, Hruschka (2010); Flikschuh (2008); Ripstein (2009).

50 RL 6:307. As this passage shows, Kant seems to think that one may either enter a juridically civil condition or cease interaction with others. This disjunctive structure is absent, or at least not apparent in his account of the ethical conditions. For reasons of space, I must set aside this point.

51 RL 6:237.

52 V-NR/Feyerabend 23:1382.

${ }^{53}$ Ripstein (2009): 328.

54 RL 6:313; KrV A 316/B 372f. See n. 47.

55 RGV 6:101-102.

56 RGV 6:101.

57 RGV 6:153.
} 
a service (cultus) of the church insofar as they direct their doctrines and regulation always to that ultimate purpose (a public religious faith). By contrast, as for the servants of a church who do not take this ultimate purpose into account at all, but who, on the contrary, declare the maxim of continual approach to it as damnable, but the attachment to the historical and statutory part of church faith as alone bringing salvation, one will rightly be able to accuse them of pseudoservice of the church ... ${ }^{58}$

This could be the ethical counterpart of legitimacy: an ethical society that did not aim to bring about pure rational faith, or even acted against the attainment of this end, simply does not count as an ethical society at all.

\section{Exiting the Ethical State of Nature}

This section continues with the comparison between the state of nature and the civil condition in Right and in ethics by focusing on the description of the ethical state of nature at the beginning of the third piece of the Religion. This provides at least two clues for a juridico-politically informed interpretation of why individuals should exit the ethical state of nature and enter an ethically civil (or ethico-civil) condition. The first clue concerns assurance, the second publicity. I take each in turn.

\subsection{Assurance}

An individual in the juridical state of nature is under no enforceable obligation to respect other individuals' rights "unless everyone else provides [that individual] assurance that [they] will behave in accordance with the same principle." ${ }^{59}$ The obligation arises only with the establishment of a public authority capable of forcing individuals to respect each others' rights. The details of Kant's difficult argument do not concern us here. ${ }^{60}$ What is important is that, according to Kant, the requirement to seek assurance arises independently of whether individuals are actually in conflict with each other. In fact, it is in the Religion that Kant distances himself from Hobbes in this regard, amending Hobbes's definition of state of nature from "bellum omnium in omnes" (a war of everyone against everyone), to "status belli [omnium in omnes]" 61 (a condition, state, Zustand of war of everyone against everyone). As he explains,

[f]or, even if one does not concede that actual hostilities always prevail among human beings who are not subject to external and public laws, yet their situation (status iuridicus) ... is a situation in which each human being wants to be himself the judge concerning what is to be right for him as against others, yet also has for this no security from others nor gives any to them, each having only his own power-which is a situation [or state - WP] of war, in which everyone must constantly be armed against everyone. ${ }^{62}$

\footnotetext{
58 Ibidem.

59 RL 6:256.

60 See Ripstein (2009), 159-168.

${ }^{61}$ RGV 6:97 n., emphases altered.

${ }^{62}$ Ibidem. See also V-MS/Vigil 27:591.
} 
In the Religion, Kant explains that the mere co-existence of a plurality of human beings is sufficient for each of them to risk relapsing into evil (\$1.2):

if [one] looks around for the causes and circumstances that brings this danger upon him and keep him in it, he can easily convince himself that they come to him not so much from his own crude nature, insofar as he is there separately, as from human beings with whom he stands in relation or associations ... there is not even any need to presuppose these latter as already sunk in evil and as examples misleading others: it suffices that they are there, that they surround him, and that they are human beings, in order to corrupt one another in their moral predisposition and make one another evil. ${ }^{63}$

Consistently with his amendment of Hobbes's definition of juridical state of nature in the Religion, in the Doctrine of Right Kant writes that in order to be authorised to force others into the civil condition "it is not necessary to wait for actual hostility; one is authorised to use coercion against someone who already, by his nature, threatens him with coercion" ${ }^{\prime 64}$. Similarly, in the Religion, it is the mere presence of others around one that generates the risk of relapsing into evil, and the corresponding duty to exit the ethical state of nature.

Applying Kant's assurance argument to the ethical sphere, we might say the following: whereas in the juridical-political sphere assurance has to do with rights, individuals outside an ethico-civil condition provide each other no assurance against the evil principle residing in each of them. Of course, this lack of assurance does not authorise coercing others into an ethico-civil condition, since this is conceptually and normatively impossible (\$2.1). Still, it is only by exiting the ethical state of nature that individuals can provide assurance regarding their intention to uphold the good principle. I provide more details on this point later in this section (§3.3).

\subsection{Private and Public Grounds for Belief}

Our second clue concerns publicity, and can be articulated in two ways. ${ }^{65}$ Firstly, we have seen that the goal of approximating a pure rational faith must shape the action of any ethical society (\$2.4). Rational faith (Vernunftglaube) is a technical term for Kant. His theory of propositional attitudes distinguishes opinion (Meinung), knowledge (Wissen), and belief or faith (Glaube). As Leslie Stevenson explains, "Kant sees meinen and wissen as different grades on the same scale of theoretical justification [but] glauben is not on that scale at all, it does not compete in the theoretical stakes." ${ }^{66}$ Unlike opinion and knowledge, Glaube does not and cannot be warranted on epistemic grounds, but solely on practical ones; and yet, like knowledge and unlike opinion, Glaube has objective validity.

\footnotetext{
${ }^{63}$ RGV 6:93-94.

${ }^{64}$ RL 6:307; see n. 17.

${ }^{65}$ I focus only on one sense of publicity. Demiray (2017) discusses a sense concerning church officials. See n. 48.

${ }^{66}$ Stevenson (2003): 86.
} 
The most important instance of Glaube, and the most relevant for us, is pure rational faith. This is ultimately based on our consciousness of the moral law -Kant's famous Fact of Reason. ${ }^{67}$ The Fact of Reason warrants Glaube in God as a "postulate of pure practical reason," ${ }^{68}$ namely a theoretically indemonstrable but morally necessary proposition. ${ }^{69}$ Importantly for my purposes, this warranting relation can be thought of as mediated by Glaube in the Highest Good - namely, in the apportioning of happiness in proportion to virtue. ${ }^{70}$ To simplify Kant's argument, God is necessary for this apportioning because what is in our power is only our morality, which is indeed the unconditional, but not the complete good. The latter is precisely happiness in proportion to virtue. ${ }^{71}$ The mediated nature of our belief in God as moral legislator and, most importantly, "moral ruler of the world"72 consists in the fact that it depends on the Highest Good, which, in turn, is based on the Fact of Reason. ${ }^{73}$

Now, it has been argued that our propositional attitude regarding the Fact of Reason is characterised by subjectivity and incommunicability, while at the same time retaining its objective validity in virtue of its practical nature. ${ }^{74}$ What matters for my purposes is that thanks to its mediated nature, Glaube in God as moral legislator and ruler, the core component of pure rational faith, is based on grounds that are communicable, namely, the Highest Good. This means that, unlike the historical element of religion, which likely falls under mere opining in virtue of the idiosyncratic, private nature of its grounds, pure rational faith is based on shareable, public grounds. ${ }^{75}$ This is supported by the fact that in the Religion Kant mentions the Highest Good in the context of his argument for the duty to exit the ethical state of nature:

Now, here we have a duty of its own kind ... the furtherance of the highest good as a common good. However, the highest moral good is not brought about through the endeavour of the individual person for his moral perfection alone, but requires that those rational beings unite for this same purpose to form a whole as a system of well-meaning human beings, in which and through the unity of which alone this good can come about; yet the idea of such a whole, as the idea of a universal republic according to laws of virtue, is an idea entirely distinct from all moral laws (which concern what we know to be in our power), namely to work toward a whole of which

\footnotetext{
67 KpV 5:31.

${ }^{68} \mathrm{KpV} 5: 124$

${ }^{69} \mathrm{KpV}$ 5:122. For simplicity's sake, I set aside the discussion of the other two postulates, freedom and immortality.

${ }^{70} \mathrm{KpV}$ 5:124-125. On the Highest Good, see Bader (2015).

${ }^{71} \mathrm{KpV}$ 5:110.

72 RGV 6:99.

${ }^{73}$ Pasternack (2011): 312.

74 Ibidem: 310-315.

${ }^{75}$ In the first Critique, Kant writes: "persuasion can indeed not be distinguished subjectively from conviction if the subject views the assent merely as an appearance of his own mind. But the assent's bases that are valid for us can be tested on the understanding of others, to see whether these bases have the same effect on the reason of others that they have on ours; and this test is still a means, although only a subjective one, not indeed to bring about conviction, but still to detect any merely private validity of the judgment, i.e., whatever in the judgment is mere persuasion." (KrV A 821/B 849).
} 
we cannot know whether, as such, it is also in our power. Thus the duty is, according to its kind and its principle, distinct from all others. - The reader is probably already suspecting in advance that this duty will need the presupposition of another idea, namely that of a higher moral being through whose universal arrangement the forces of the individuals, insufficient by themselves, are united to yield a common effect. ${ }^{76}$

Note that Kant's argument that the Highest Good requires union in an ethical community does not concern the highest complete good, happiness in proportion to virtue - although that is on his mind too (recall his reference to God as moral ruler) - but rather the highest supreme good, virtue. The reason is that the argument is prompted by the danger of relapsing under the dominion of evil (\$1.2). ${ }^{77}$

The first way in which publicity bears on the duty to exit the ethical state of nature can be summarised by saying that this exit means entering an ethical society which, if it is to be such, must have as its goal approximation of pure rational faith (\$2.4), which is based on public (shareable, non-idiosyncratic) grounds.

\subsection{A Public Commitment to the Good}

Turning to the second way in which publicity is relevant to exit from the ethical state of nature, let us begin with this passage:

Morally legislative reason, apart from the laws that it prescribes to each individual, also hangs out in addition a flag of virtue as a point of union for all who love the good, that they may assemble beneath it and thus first gain the upper hand over the evil that untiringly challenges them. ${ }^{78}$

We already know that, according to Kant, individuals must exit the ethical state of nature because of the risk of relapsing into evil, which has a social origin (\$3.1). I believe that Kant's "flag of virtue" adds to this picture the idea of a public commitment to the good. Whereas an individual may already be committed to the good principle, in the ethical state of nature that commitment remains private. Entrance in an ethico-civil condition consists in a public signalling, a public communication of one's commitment. This can be articulated in three points.

Firstly, although one might think that this communication may be empty or trivial (after all, who would state that they are not committed to the good?) ${ }^{79}$ with the introduction of a "point of union," under which those "who love the good" 80 can assemble,

\footnotetext{
${ }_{76}$ RGV 6:97-98.

77 Moreover, it cannot be up to human beings to distribute happiness in accordance with virtue because only God has access to the depths of individuals' motives (RGV 6:99; see §4.4).

${ }^{78}$ RGV 6:94. I set aside the fact that Kant's "first gain the upper hand" (ibidem, emphasis added) seems at odds with his previous statement that exiting the ethical state of nature is meant to prevent a relapse into evil (\$1.2) - which presupposes that the upper hand has already been gained by the individual, however precariously.

${ }^{79}$ Particularly given that Kant excludes the possibility of diabolical evil for human beings (RGV 6:35).

${ }^{80}$ RGV 6:94.
} 
some of our moral relations gain a new strength, particularly those concerning moral responsibility: if you claim to be a member of this community, why are you not living according to its standards? ${ }^{81}$

Secondly, and relatedly, thanks to its publicity the individual's commitment to the good gains a new strength in the individual's own eyes by virtue of becoming intersubjective. The individual becomes aware of not being alone in the fight against the evil principle, and the influence of morality on the individual is strengthened.

Finally, it is worth noting that the standards of each ethical society must ultimately correspond, on Kant's theory, to those of Kantian morality. Unsurprisingly, then, the plausibility of Kant's duty to enter the ethical community depends on that of his moral theory, as the only one which supports, and indeed is captured by true moral faith. This interacts with the first sense in which publicity operates in the argument for exiting the ethical state of nature (\$3.2): a public commitment to the good principle is possible only on the basis of pure rational faith, which has its core in (Kantian) morality. So long as other, spurious, private elements are still present in the community's faith, it is always possible for one to retreat to them at one's convenience, even while still claiming to be committed to the good (in a way that, for Kant, would simply amount to lip service).

We are now in a position to summarise how the two elements explored in this section-assurance and publicity - indicate why individuals are under a duty to exit the ethical state of nature. Recall that the juridical state of nature is characterised by a certain moral incoherence (\$1.1). Within it, individuals are under no enforceable obligation to respect each other's rights unless everyone provides assurance that rights will be respected, which requires the creation of a public and coercively effective authority (\$3.1). Now, the ethical state of nature cannot have to do with coercion and rights. However, its structure can be likened to that of the juridical state of nature if we focus on the effectiveness of one's moral efforts and on the social nature of the risk of relapsing into evil. As to the first, although the single individual may well be virtuous to a sufficient degree and comply with her duties, she might see her struggles as ultimately futile if they are not inscribed in a collective effort, and might worry that the highest supreme good in its collective sense may never come about. ${ }^{82}$ As to the second, regardless of one's subjective sense of safety from the danger of relapsing into evil, one's position remains precarious in that respect. It may be the case that one could lead one's life without actually relapsing: however, one's success in doing so would still be a contingent matter. ${ }^{83}$

\footnotetext{
${ }^{81}$ On Kant's theory, we belong to the moral community of finite rational beings by default, so to speak. This is why such relations do not arise with entrance in the ethico-civil condition, and hence I speak in terms of degree.

${ }^{82}$ A similar concern is raised by Kant in his discussion of the righteous atheist in the third Critique (KU 5:452-453).

${ }^{83}$ The account in this section raises two important questions which, for reasons of space, I cannot address: assuming their commitment to morality is sincere, are those who choose to remain outside the ethical community ultimately irrational? And, would they actually be guilty of a sort of moral recklessness in virtue of choosing to be exposed to the risk of relapsing under the dominion of evil? A further, but related question would be: how should they be seen by members of the ethical community of which they refuse to be a part? On the latter question, see n. 17. See also n. 50 .
} 


\section{Functions of the Ethico-Civil Condition}

This section looks at some functions of the ethico-civil condition - what is involved in membership to an actual ethical society. For ease of exposition, I distinguish three dimensions: political, moral-organisational, and moral proper; and divide the last one in two parts.

\subsection{The Political Function}

It is plausible to think that the ethico-civil condition provides a motivational back-up to coercion, with reference to compliance with the state's positive laws and more generally to the juridico-civil condition. Think, for example, of cases of ineffectiveness of a state's coercive apparatus (an executive power unable to enforce laws reliably); of circumstances in which, despite a state's coercive apparatus being generally reliable, an individual would get away with committing a crime; and, possibly, also of cases of temporary voids in positive legislation.

In these cases, membership to an ethical society can be expected to increase the likelihood of compliance with laws by strengthening the influence of the non-coercive incentive of respect for the law on the individual, as well as the individual's resistance against the temptation of transgression. ${ }^{84}$ Kant hints at this political function when writing:

Every political community may indeed wish that a dominion over minds according to laws of virtue may be found in it as well; for where the coercive means of dominion are not sufficient ... there the virtuous attitudes would bring about what is required.$^{85}$

\subsection{The Moral-Organisational Function}

Another plausible function of an ethical society is the coordination of its members with regard to the fulfilment of their non-juridical duties (with which members are under no enforceable obligation to comply) ${ }^{86}$ Take beneficence. An ethical society could direct the spontaneous efforts of its members toward purposes deemed more worthy, or toward more efficient means to reach the community's intent.

A further moral-organisational dimension of an ethical society concerns the determination of how its members are to discharge their wide duties - through, roughly, advising and persuading. Admittedly, this dimension is not prominent in the texts.

\footnotetext{
${ }^{84}$ The first example I mentioned is tricky, as a state generally unable to enforce laws might be illegitimate (see Lo Re (forthcoming)).

${ }_{85}$ RGV 6:95.

${ }^{86}$ Katrin Flikschuh has argued that the notion of co-ordination is alien to Kant's Kingdom of Ends (Flikschuh (2010): 137). I am inclined to agree, provided that her suggestion of an identification of the Kingdom of Ends with the ethical community does not extend to actual ethical societies - which, I am arguing, are characterised by an organisational function. Relating the Kingdom of Ends to the ethical community (and to ethical societies) falls outside the scope of this paper. My hunch is that these notions should be kept separate, but I leave this discussion for another day. On the notion of community, see Payne and Thorpe (2011).
} 
However, introducing it helps us to make sense of Kant's comparison between the two states of nature, which, at points, almost seems too tight:

In both [states of nature] each person legislates to himself, and there is no external law to which he, along with everyone else, might recognise himself to be subjected. In both each person is his own judge, and there is no public power-holding authority that might with legal force [or "with legal power" (rechtskräftig) - WP] determine, according to laws, what is each person's duty in occurring cases, and bring those laws to the point of being carried out universally. ${ }^{87}$

I already mentioned persuasion, arguably the main way a non-coercive organisation could bring about any result. "With legal force" should not put us off track here: it is probably just an allusion to the fact that the power of an ethical society, while still non-coercive, operates through valid, public laws. What is curious is that Kant here speaks of an authority determining individuals' duties in specific cases starting from general laws (the passage clearly hints at the three powers of a state). I introduced the element of advice, or of guidance regarding members' conduct in an attempt to make sense of Kant's analogy here. Not only can officials (and, presumably, other members of the society) advise members on what to do, but they can also identify vices and, perhaps, instruct on how to rectify moral mistakes.

\subsection{The Moral Function: Compliance with Duties}

In the Religion, Kant mentions some moral flaws of individuals that can be brought under the jurisdiction, so to speak, of ethical societies:

secret falsity even in the most intimate friendship ... a propensity to hate the person to whom one is obligated, for which a benefactor must always be prepared; ... a heartfelt benevolence that nonetheless admits the observation, "In the misfortune of our best friends there is something that does not entirely displease us"; and ... many other vices still hidden under the semblance of virtue, not to mention the vices of those who make no secret of them at all ... ${ }^{88}$

Fostering mutual trust and openheartedness, gratitude, and genuine benevolence are all plausible examples of the kind of concrete moral work with which an ethical society can task itself. It is plausible to believe that this extends to most duties of virtue. In addition to this, an ethical society can be expected to look after the moral worth of the actions of its members - to strengthen the influence of the moral incentive; and, to increase their resistance against temptations (the real mark of virtue in a human being). ${ }^{89}$

\footnotetext{
${ }^{87}$ RGV 6:95.

${ }^{88}$ RGV 6:33.

${ }^{89}$ TL 6:394.
} 


\subsection{The Moral Function: Fighting Radical Evil by Promoting Truthfulness}

A second aspect of the moral dimension of ethical societies is rather obscure in virtue of being connected with two of the most mysterious doctrines of Kant's moral philosophy - radical evil (\$1.2) and the ethical duty not to lie. ${ }^{90}$ The relation between the latter two is a complicated matter, but arguably both have to do with a certain fundamental moral self-deception, through which deviation from the moral law first becomes possible. ${ }^{91}$ There are many passages which signal a close connection between the ethical sense of lying and radical evil. For example, in the Religion Kant writes:

All professed reverence to the moral law, if yet in one's maxim it does not concede to the law, as incentive sufficient by itself, preponderance over all other determining bases of the power of choice, is hypocritical; and the propensity to such reverence is inward falsity, i.e., a propensity to lie to oneself in interpreting the moral law to its detriment ... This is why the Bible ... calls the originator of evil (who resides within ourselves) the liar from the beginning, and thus characterises the human being in regard to what seems to be the main basis of evil in him. ${ }^{92}$

Compare the following passage in the section on lying in the Doctrine of Virtue:

It is noteworthy that the Bible dates the first crime, through which evil entered the world, not from fratricide (Cain's) but from the first lie ... and calls the author of all evil a liar from the beginning and the father of lies. However, reason can assign no further ground for the human propensity to hypocrisy (esprit fourbe), although this propensity must have been present before the lie; for, an act of freedom cannot (like a natural effect) be deduced and explained in accordance with the natural law of the connection of effects with their causes, all of which are appearances..$^{93}$

Finally, in On the Miscarriage of all Philosophical Trials in Theodicy, Kant writes,

Now the formal conscientiousness which is the ground of truthfulness consists precisely in ... not pretending to hold anything as true we are not conscious of holding as true. Hence, if someone says to himself (or - what is one and the same in religious professions - before God) that he believes, without perhaps casting even a single glimpse into himself - whether he is in fact conscious of thus holding a truth or at least of holding it to some degree - then such a person lies. And not only is his lie the most absurd (before a reader of hearts): it is also the most sinful, for it undermines the ground of

90 TL 6:429-431. For reasons of space, I can only provide a rough sketch of this duty. For a discussion, see Bacin (2013). For an account of Kant's threefold taxonomy of senses of lying, see Mahon (2009).

${ }^{91}$ Bacin argues that while the ethical sense of lying is closely connected to radical evil, it should not be identified with it (Bacin (2013): 254 n. 32).

${ }_{92}$ RGV 6:42 n.

${ }^{93}$ TL 6:431. Kant also claims that the propensity to evil is "characterised by a certain insidiousness of the human heart ... in deceiving itself concerning its own good and evil attitudes" (RGV 6:38). 
every virtuous intention, sincerity [weil sie den Grund jedes tugendhaften Vorsatzes, die Aufrichtigkeit, untergräbt]. It is not difficult to see how quickly these blind and external professions (which can very easily be reconciled with an internal profession just as false) can, if they yield means of gain, bring about a certain falsehood in a community's very way of thinking. ... [A] public purification of this way of thinking [diese öffentliche Läuterung der Denkungsart] must in all likelihood be deferred to a distant future ... ${ }^{94}$

Lying to oneself is akin to lying to God, and this inner lie "undermines the ground of every virtuous intention, sincerity." ${ }^{95}$ However, this kind of mendacious verbal self-deception can never be completely successful. ${ }^{96}$ This is the flip side of the paradox that radical evil is self-incurred (\$1.2): moral self-deception can never go as far as erasing the principle of the good in us. Lying before God is absurd; and, while deceiving ourselves is possible, it is possible only to a certain extent. Ultimately, our bad intentions always come with moral residue, however rationalised.

Most important for my purposes is Kant's reference to the relation between lying and "blind external professions of faith." ${ }^{17}$ The latter likely fall within the scope of the superstitious and fanatic religious attitude that Kant sets out to oppose (\$2.4). Crucially, his allusion to the necessity of a "public purification" 98 of individuals' way of thinking seems to correspond precisely to a parallel development of pure rational faith in a community (\$§3.2-3). This is telling with regard to the role of ethical societies (which, recall, must adopt the goal of this development). Although adequately exploring the connection between lying, faith, and the ethical community would take us too far afield, three final points can be made.

Firstly, given the centrality of truthfulness within Kant's moral theory, it is plausible to believe that he takes ethical societies to play an important role of vigilance with regard to lying to others. This may even be coupled with the possibility of dispensing an ethical analogue of punishment to members who are caught lying - for example, some form of social ostracism; or simply with an increased internalised awareness on the part of the liar of her worthlessness. ${ }^{99}$

Secondly, in virtue of adopting the development of pure rational faith as its purpose, an ethical society can also be expected to contribute to gradually overcoming "blind external professions." Recall that, according to Kant, pure rational faith is based on moral grounds (\$3.2). This provides the basis for conceiving of mechanical and contrived expressions of faith as presupposing a degree of inward falsity: assuming the truth of Kant's moral argument in favour of, for example, the postulate of God, there can be no

\footnotetext{
${ }^{94}$ MpVT 8:268-269, footnote removed, trans. altered.

${ }_{95}$ MpVT 8:269.

${ }_{96}$ Verbal deception can occur by means other than lies, and deception can occur by non-linguistic means. See n. 90.

97 Ibidem.

98 Ibidem, emphasis added.

99 The worthlessness of a liar is mentioned at various points (e.g. VRML 8:426 n.; TL 6:403; KpV 5:93). The two dynamics in the main text are present in Kant's views on education (e.g. Päd 9:482; see also $\mathrm{V}-\mathrm{PP} /$ Herder 27:60). Whereas the connection between radical evil and the ethical sense of lying has long been noted (e.g. Allison (1990): 159 n. 19. See n. 91), that between the two and the role of the ethical community in preventing relapsing under evil is, as far as I am aware, unexplored.
} 
doubt that such professions are spurious; and, insofar as they are pernicious for morality and for pure rational faith, they must be overcome. ${ }^{100}$ Another type of untruthfulness in religious matters comes not from the impurity of grounds for belief, but rather from an alleged theoretical nature of grounds for belief. Kant speaks of lying in terms not only of stating what one believes to be false, but also of "giv[ing] out as certain ... what [one] nevertheless knows [oneself] to be subjectively uncertain of."101

Thirdly, and finally, these requirements of inner and outer truthfulness in matters of religion (do not claim belief in spurious beliefs! Do not claim theoretically grounded belief in what is impossible to believe on theoretical grounds!) are intertwined with self-deception about one's conduct: for example, believing that one is acting solely on the basis of the moral incentive when one is not; or convincing oneself of the permissibility of occasionally deviating from one's duty. It is plausible to believe that, in virtue of its diametrical opposition to anything that is not sincere, the ethical society is thought by Kant as having an important role against this kind of self-deception.

To summarise, we can say that, as a result of its commitment to sincerity, the ethical society has a bidirectional function: it purifies both individuals' morality on the basis of religion and their religion on the basis of morality. ${ }^{102}$

\section{Conclusion}

This paper suggested that Kant's use of the notions of the state of nature and of the civil condition in the ethical-religious sphere goes beyond merely illustrative purposes. The comparison between the juridical and the ethical conditions speaks in favour of thinking that their relation is deeper than the Religion might reveal at a first glance. This provides a basis for developing a unitary conception of the state of nature and of the civil condition, which would underlie both the juridical and the ethical version. This paper made no step in that direction, although it did provide some preliminary elements for such a task, as well as directions for further inquiry. In doing so, it furthered the parallel between the legal-political and the ethical-religious spheres of Kant's philosophy. Recall that Right is "the sum of the conditions under which the choice of one can be united with the choice of another in accordance with a universal law of freedom." ${ }^{103}$ With the due differences, one might venture to say that Kant's account in the Religion is a sketch of the conditions under which the commitment to the good principle of one can be united with that of others - without external coercion, and in communal opposition to the evil principle.

\footnotetext{
${ }^{100}$ For reasons of space, I cannot address the complex relation between Kant's moral theory and the Christian religion (see e.g. RGV 6:125; KpV 5:127).

${ }^{101}$ VNAEF 8:422. This does not mean that Kant's moral faith is necessarily characterised by an element of uncertainty. Recall that belief in God is based on belief in the Highest Good. The latter, in turn, rests upon the Fact of Reason, which, for Kant, is indubitable, although based on practical (and not theoretical) grounds (\$3.2).

${ }^{102}$ A further direction of research concerning the relation between ethical and juridical conditions regards the link between the role of ethical societies with regard to sincerity on the one hand, and Kant's juridical duties against lying on the other.

${ }^{103}$ RL 6:230; see §1.1.
} 


\section{References}

Allison H.E. (1990), Kant's Theory of Freedom, Cambridge University Press, Cambridge.

Bacin S. (2013), “The Perfect Duty to Oneself Merely as a Moral Being (TL 6:428-437)," [in:] Kant's Tugendlehre: A Comprehensive Commentary, A. Trampota, O. Sensen, J. Timmermann (eds.), Walter de Gruyter, Berlin: 245-268.

Bader R.M. (2015), "Kant's Theory of the Highest Good," [in:] The Highest Good in Aristotle and Kant, J. Aufderheide, R.M. Bader (eds.), Oxford University Press, Oxford: 183-213.

Byrd B.S., Hruschka J. (2008), "From the State of Nature to the Juridical State of States," Law and Philosophy 27 (6): 599-641.

Demiray M.R. (2017), "Public Religion and Secular State: A Kantian Approach," Diametros 54 (54): 30-55.

Ebels-Duggan K. (2012), “Kant's Political Philosophy," Philosophy Compass 7 (12): 896-909.

Flikschuh K. (2017), What is Orientation in Global Thinking?: A Kantian Inquiry, Cambridge University Press, Cambridge.

Flikschuh K. (2010), “Kant's Kingdom of Ends: Metaphysical, not Political,” [in:] Kant's Groundwork of the Metaphysics of Morals: A Critical Guide, J. Timmermann (ed.), Cambridge University Press, Cambridge: 119-139.

Flikschuh K. (2008), “Sidestepping Morality: Korsgaard on Kant's No-Right to Revolution," Jahrbuch für Recht und Ethik 16: 127-145.

Flikschuh K. (2000), Kant and Modern Political Philosophy, Cambridge University Press, Cambridge.

Formosa P. (2007), "Kant on the Radical Evil of Human Nature," The Philosophical Forum 38 (3): 221-245.

Hasan R. (2018), “The Provisionality of Property Rights in Kant's Doctrine of Right," Canadian Journal of Philosophy 48 (6): 850-876.

Kain P. (2004), "Self-Legislation in Kant's Moral Philosophy," Archiv für Geschichte der Philosophie 86 (3): 257-306.

Kant I. (1784/2016), Natural Right Course Lecture Notes by Feyerabend, trans. F. Rauscher, [in:] I. Kant, Lectures and Drafts on Political Philosophy, F. Rauscher, K.R. Westphal (eds.), Cambridge University Press, Cambridge: 73-180.

Kant I. (1785/2011), Groundwork of the Metaphysics of Morals, M.J. Gregor, J. Timmermann (eds., trans.), Cambridge University Press, Cambridge.

Kant I. (1793/2009), Religion within the Bounds of Bare Reason, trans. W.S. Pluhar, Hackett Publishing, Indianapolis.

Kant I. (1803/2007), Lectures on Pedagogy, trans. R.B. Louden, [in:] I. Kant, Anthropology, History, and Education, G. Zöller, R.B. Louden (eds.), Cambridge University Press, Cambridge: 434-485.

Kant I. (1796/2002a), Proclamation of the Imminent Conclusion of a Treaty of Perpetual Peace in Philosophy, trans. P. Heath, [in:] I. Kant, Theoretical Philosophy after 1781, H. Allison, P. Heath (eds.), Cambridge University Press, Cambridge: 451-460.

Kant I. (1788/2002b), Critique of Practical Reason, trans. W.S. Pluhar, Hackett Publishing, Indianapolis.

Kant I. (1793/1997a), Kant on the Metaphysics of Morals: Vigilantius's Lecture Notes, trans. P. Heath, [in:] I. Kant, Lectures on Ethics, P. Heath, J.B. Schneewind (eds.), Cambridge University Press, Cambridge: 249-452. 
Kant I. (1763/1997b), Kant's Practical Philosophy: Herder's Lecture Notes, trans. P. Heath, [in:] I. Kant, Lectures on Ethics, P. Heath, J.B. Schneewind (eds.), Cambridge University Press, Cambridge: 1-36.

Kant I. (1797/1996a), On a Supposed Right to Lie from Philanthropy, trans. M.J. Gregor, [in:] I. Kant, Practical Philosophy, M.J. Gregor (ed.), Cambridge University Press, Cambridge: $605-616$.

Kant I. (1797/1996b), The Metaphysics of Morals, trans. M.J. Gregor, [in:] I. Kant, Practical Philosophy, M.J. Gregor (ed.), Cambridge University Press, Cambridge: 353-604.

Kant I. (1795/1996c), Toward Perpetual Peace, trans. M.J. Gregor, [in:] I. Kant, Practical Philosophy, M.J. Gregor (ed.), Cambridge University Press, Cambridge: 311-352.

Kant I. (1793/1996d), On the Common Saying: That May Be Correct in Theory, But It Is of No Use in Practice, trans. M.J. Gregor, [in:] I. Kant, Practical Philosophy, M.J. Gregor (ed.), Cambridge University Press, Cambridge: 273-310.

Kant I. (1791/1996e), On the Miscarriage of all Philosophical Trials in Theodicy, trans. A.W. Wood, G. Di Giovanni, [in:] I. Kant, Religion and Rational Theology, A.W. Wood, G. Di Giovanni (eds.), Cambridge University Press, Cambridge: 19-38.

Kant I. (1786/1996f), Review of Gottlieb Hufeland's Essay on the Principle of Natural Right, trans. A.W. Wood, [in:] I. Kant, Practical Philosophy, M.J. Gregor (ed.), Cambridge University Press, Cambridge: 109-118.

Kant I. (1781/1996g), Critique of Pure Reason, trans. W.S. Pluhar, Hackett Publishing, Indianapolis.

Kant I. (1790/1987), Critique of Judgment, trans. W.S. Pluhar, Hackett Publishing, Indianapolis.

Kant I. (1900-), Kants gesammelte Schriften, Royal Prussian Academy of Sciences (ed.), Walter de Gruyter, Berlin.

Lo Re S. (forthcoming), "Supreme Power: A Neglected Source of Tension in Kant's Views on Political Resistance," [in:] Proceedings of the $13^{\text {th }}$ International Kant Congress, C. Serck-Hanssen, B. Himmelmann (eds.), Walter de Gruyter, Berlin.

Mahon J.E. (2009), “The Truth about Kant on Lies," [in:] The Philosophy of Deception, C. Martin (ed.), Oxford University Press, Oxford: 201-224.

Michalson G. (ed.) (2014), Kant's Religion within the Boundaries of Mere Reason: A Critical Guide, Cambridge University Press, Cambridge.

Morgan S. (2005), “The Missing Formal Proof of Humanity's Radical Evil in Kant's Religion," The Philosophical Review 114 (1): 63-114.

Muchnik P. (2009), Kant's Theory of Evil: An Essay on the Dangers of Self-love and the Aprioricity of History, Lexington Books, Plymouth.

Niesen P. (2007), "Colonialism and Hospitality," Politics and Ethics Review 3 (1): 90-108.

Papish L. (2018), Kant on Evil, Self-Deception, and Moral Reform, Oxford University Press, Oxford.

Payne C., Thorpe L. (eds.) (2011), Kant and the Concept of Community, University of Rochester Press, Rochester.

Pinzani A. (2008), “Representation in Kant's Political Theory," Jahrbuch für Recht und Ethik 16: 203-226.

Ripstein A. (2009), Force and Freedom: Kant's Legal and Political Philosophy, Harvard University Press, Cambridge.

Ripstein A. (2004), "Authority and Coercion," Philosophy \& Public Affairs 32 (1): 2-35.

Stevenson L. (2003), “Opinion, Belief or Faith, and Knowledge,” Kantian Review 7 (1): 72-101. 
Timmermann J. (2018), “Emerging Autonomy: Dealing with the Inadequacies of the 'Canon of Pure Reason' (1781)," [in:] The Emergence of Autonomy in Kant's Moral Philosophy, S. Bacin, O. Sensen (eds.), Cambridge University Press, Cambridge: 102-121.

Varden H. (2010), “Kant's Non-Absolutist Conception of Political Legitimacy: How Public Right 'Concludes' Private Right in the Doctrine of Right," Kant-Studien 101 (3): 331-351. 